\title{
Identifikasi Pengaruh Keruangan terhadap Angka Kesembuhan Covid-19 di Kabupaten Bekasi
}

\author{
Muhammad Faishal Hafizh* \\ Prodi Teknik Perencanaan Wilayah \& Kota, Fakultas Teknik, \\ Universitas Islam Bandung, Indonesia. \\ *hafizh730@gmail.com
}

\begin{abstract}
The spatial condition of South Tambun District is influenced by its geographical position close to Jakarta as the Central Capital City, so it cannot be denied that urbanization has affected the formation or function of land use, which is dominated by settlements. Seeing the Covid-19 phenomenon that affects all aspects of life, especially public health, it is a challenge to be able to get out of this situation, one of which is to recover or minimize the impact of this disease outbreak. Based on this phenomenon, the problem is formulated, namely how is the influence of space on environmental and physical aspects on the Covid-19 recovery rate in South Tambun District. The researcher uses a quantitative approach with multiple regression analysis methods and the supporting analysis is the entropy index and weighting of environmental quality. The research objects selected for this study were all 10 villages/kelurahan in South Tambun District. Techniques in data collection using secondary data and also satellite imagery. The results of this study are: Spatial variables on environmental and physical aspects of the Covid-19 recovery rate variable still affect the recovery indirectly.
\end{abstract}

Keywords: Spatial, Healing Covid-19, Built Environment.

Abstrak. Kondisi keruangan Kecamatan Tambun Selatan dipengaruhi oleh posisi secara geografis berdekatan dengan Jakarta sebagai Pusat Ibu Kota, sehingga tidak dapat dipungkiri terjadinya urbanisasi yang mempengaruhi bentukan ataupun fungsi penggunaan lahan, yang didominasi oleh permukiman. Melihat fenomena Covid-19 yang mempengaruhi diseluruh aspek kehidupan khususnya Kesehatan dimasyarakat, menjadi tantangan untuk dapat keluar dari situasi ini salah satunya untuk dapat sembuh atau meminimalisir terdampak dari wabah penyakit ini. Berdasarkan fenomena tersebut, maka dirumuskan permasalahnya yaitu bagaimana pengaruh keruangan pada aspek lingkungan dan fisik terhadap angka kesembuhan Covid-19 di Kecamatan Tambun Selatan. Peneliti menggunakan pendekatan kuantitatif dengan metode analisis regresi majemuk serta penunjang analisisnya adalah indeks entropi dan pembobotan kualitas lingkungan. Objek penelitian yang dipilih untuk penelitian ini adalah seluruh desa/ kelurahan di Kecamatan Tambun Selatan yang berjumlah 10 wilayah. Teknik dalam pengumpulan datanya menggunakan data-data sekunder dan juga citra satelit. Hasil dari penelitian ini adalah: Variabel keruangan pada aspek lingkungan dan fisik terhadap variabel angka kesembuhan Covid-19 tetap mempengaruhi kesembuhannya secara tidak langsung.

Kata Kunci: Keruangan, Kesembuhan Covid-19, Lingkungan Binaan. 


\section{A. Pendahuluan}

Keruangan terbentuk dari asal kata ruang, dalam Undang-undang 26 Tahun 2007 menjelaskan bahwa Ruang adalah sebuah wadah yang meliputi ruang darat, ruang laut, dan ruang udara, termasuk ruang di dalam bumi sebagai satu kesatuan wilayah, tempat manusia dan makhluk lain hidup, melakukan kegiatan, dan memelihara kelangsungan hidupnya. Sehingga dengan berbagai aktivitas yang dilakukan oleh manusia pada suatu wilayah dapat mempengaruhi bentuk atau fungsi ruang itu sendiri, hal tersebut dapat disebut dengan lingkungan binaan. Menurut Budiwdodo Pangarso dan Anastasia Anindyasarathi, Lingkungan binaan merupakan suatu kondisi pada daerah yang telah ada keberadaan sekelompok manusia yang tinggal dengan melakukan pembangunan untuk tempat tinggal baik berupa bangunan atau gedung dan infrastruktur penunjangnya, walaupun kondisinya sederhana. Jika menelisik ruang pada perkotaan khususnya di permukiman, maka tidak memiliki makna yang berasal dari dirinya sendiri, melainkan dari kehidupan di dalamnya.

Proses urbanisasi yang saat ini terjadi, menyebabkan perkembangan ruang yang cepat, sehingga berdampak pada infrastruktur alam, bangunan, kesehatan lingkungan dan kesejahteraan manusia (Zhu et al. 2011 dalam). Kondisi inilah yang akan mempengaruhi munculnya lokasi-lokasi permukiman yang tidak terarah secara kualitas dan kuantitasnya. Permukiman ini akan rentan dengan berbagai masalah kesehatan, mulai dari penyakit menular maupun tidak menular.

Melihat kondisi diseluruh dunia saat ini, hampir terjangkit dengan wabah penyakit menular yaitu Corona Virus Disease 2019 (Covid-19). Virus corona yang sedang berlangsung ini adalah contoh dari hubungan erat antara pembangunan perkotaan dan penyakit menular baru atau yang muncul kembali. Seperti pandemi SARS tahun 2003, hubungan antara urbanisasi yang dipercepat, sarana transportasi yang lebih luas dan lebih cepat, serta jarak yang lebih jauh antara kehidupan perkotaan dan alam non-manusia karena pertumbuhan yang berkelanjutan di pinggiran kota serta terjadi infeksi trans spesies dikemudian hari menjadi segera terlihat. Ketidakseimbangan ini juga mempengaruhi reaksi terhadap wabah.

Berdasarkan uraian pada latar belakang di atas, maka rumusan masalah dalam penelitian ini adalah bagaimana pengaruh keruangan pada aspek lingkungan dan fisik terhadap angka kesembuhan Covid-19 di Kecamatan Tambun Selatan. Dengan tujuan penelitiannya yaitu Mengetahui pengaruh keruangan pada aspek lingkungan dan fisik terhadap angka kesembuhan Covid-19 di Kecamatan Tambun Selatan.

\section{B. Metodologi Penelitian}

Pada penelitian ini menggunakan metode analisis statistik yaitu regresi majemuk untuk mendapatkan pengaruh keruangan pada aspek lingkungan dan fisik terhadap angka kesembuhan Covid-19, dan menggunakan pendekatan kuantitatif. Objek atau sampel yang dipilih untuk penelitian ini yaitu desa/kelurahan pada Kecamatan Tambun Selatan dengan jumlah 10 Desa/Kelurahan. Teknik yang digunakan terkait dengan pengumpulan data pada penelitian ini yaitu berupa data sekunder (Instansi dan Citra Satelit). Adapun data-data sekunder tersebut berkaitan dengan variabel penelitian yang meliputi:

Simbol

\begin{tabular}{lr|c} 
Variabel Independen $(\mathrm{X}) \quad: \quad$ V1 & $=$ Luas RTH & RTH \\
& V2 $=$ Keragaman Penggunaan Lahan & PL \\
& V3 $=$ Kenyamanan dan Layak Huni & KLH \\
V4 & $=$ Fasyankes Penanganan Covid-19 & FP \\
Variabel Dependen (Y) $\quad: \quad$ V5 & $=$ Angka Kesembuhan Covid-19 & AKC
\end{tabular}

Namun data yang dibutuhkan khusus pada variabel keragaman penggunaan lahan maupun kenyamanan dan layak huni, diperoleh menggunakan pendekatan analisis terlebih 
dahulu diantaranya yaitu:

1. Indeks Entropi

Indeks Entropy merupakan sebuah pendekatan pada tingkat penggunaan lahan campuran di suatu wilayah tertentu, dengan memperhitungkan persentase relatif dari jenis-jenis penggunaan lahannya (Turner, Gardner, \& O’Neill (2001) dalam (6)), dengan persamaan berikut:

$$
E I=(-1) \times \frac{\left\lfloor\left(\frac{b 1}{a}\right) \times \ln \left(\frac{b 1}{a}\right)+\left(\frac{b 2}{a}\right) \times \ln \left(\frac{b 2}{a}\right)+\ldots+\left(\frac{b i}{a}\right) \times \ln \left(\frac{b i}{a}\right)\right\rfloor}{\ln (n)}
$$

Keterangan:

$E I=$ Indeks Entropy

$\mathrm{b}_{1}, \mathrm{~b}_{2}, \mathrm{~b}_{\mathrm{i}}=$ Luas permasing-masing guna lahan

$\mathrm{a}=$ Jumlah luas lahan

$\ln (\mathrm{n})=$ kontanta dari jumlah guna lahan

Tabel 1. Contoh perhitungan Indeks Entropi pada Desa Jatimulya

\begin{tabular}{|l|l|l|}
\hline Nomor & Nilai EI & Tingkat Penggunaan Lahan Campuran \\
\hline 1 & $0-0,20$ & Sangat Rendah \\
\hline 2 & $0,21-0,40$ & Rendah \\
\hline 3 & $0,41-0,60$ & Sedang \\
\hline 4 & $0,61-0,80$ & Tinggi \\
\hline 5 & $0,81-1,00$ & Sangat Tinggi \\
\hline
\end{tabular}

Sumber: Bahadure \& Kotharkar (2015, dalam Segnita \& Handayani, 2017)

2. Kenyamanan dan layak huni berikut:

Pada analisis ini menggunakan pembobotan kualitas lingkungan melalui proses sebagai

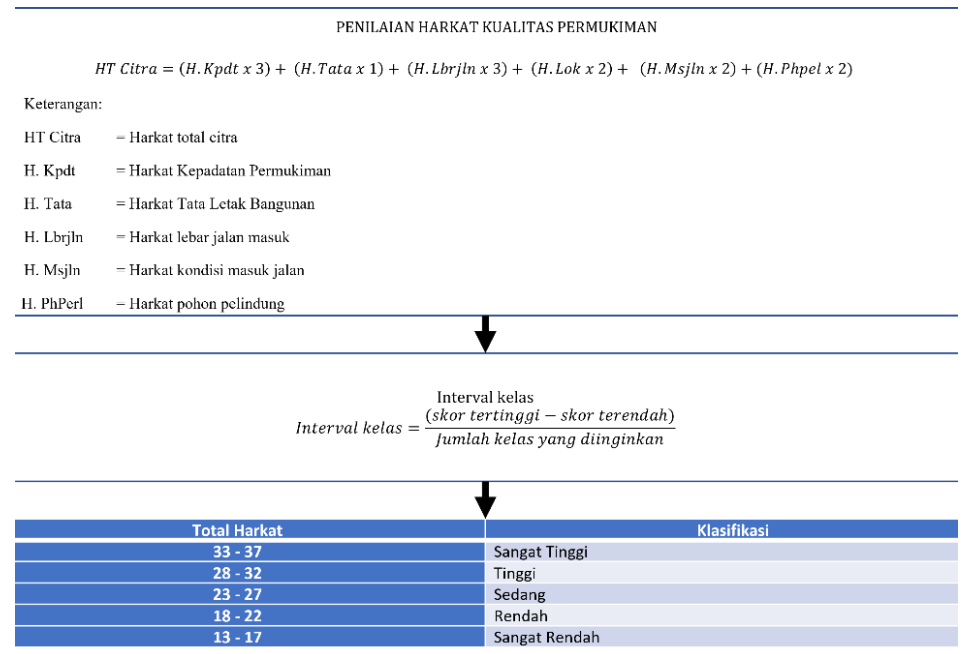

Gambar 1. Alur analisis pembobotan kualitas lingkungan Sumber: Diolah oleh Peneliti, 2021 


\section{Hasil Penelitian dan Pembahasan}

\section{Analisis Keragaman Penggunaan Lahan}

Berikut data yang dihasilkan melalui proses digitasi penggunaan lahan pada masing-masing desa/kelurahan di Kecamatan Tambun Selatan. Dengan kondisi penggunaan lahan yang dominan pada Kecamatan Tambun Selatan adalah Permukiman seperti pada gambar 2. Kemudian dilanjutkan pada proses perhitungan indeks entropi menggunakan excel, dengan ketentuan rasio nilai yang akan didapatkan pada rentan $0-1$, semakin besar nilai pada indeks entropy atau mendekata angka 1 maka semakin tinggi keragaman penggunaan lahannya, seperti contoh perhitungan indeks entropi pada tabel 1 .

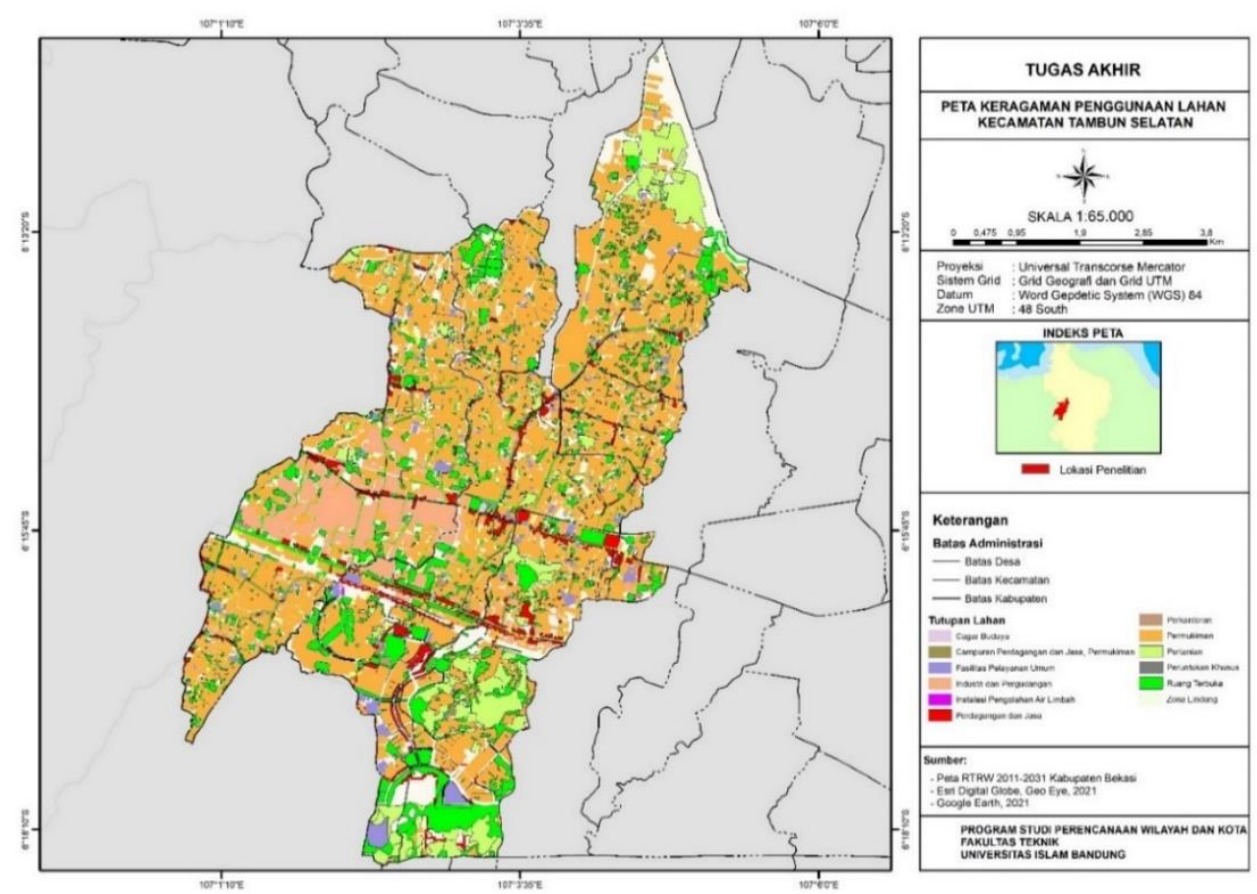

Gambar 2. Peta Keragaman Penggunaan Lahan di Kecamatan Tambun Selatan

Sumber: Diolah oleh Peneliti, 2021

Tabel 1. Contoh perhitungan Indeks Entropi pada Desa Jatimulya

\begin{tabular}{|c|c|c|c|c|c|c|c|}
\hline Desa & Kode & $\mathrm{n}$ & Jenis TGL & $\begin{array}{l}\text { Luas } \\
\text { (Ha) }\end{array}$ & b/a & $\ln (\mathbf{b} / \mathbf{a})$ & $\begin{array}{c}\operatorname{sum}(b / a) x \\
(\ln (b / a)\end{array}$ \\
\hline \multirow{10}{*}{$\begin{array}{c}\text { Jatimul } \\
\text { ya }\end{array}$} & i1 & 1 & $\begin{array}{l}\text { Campuran Perdagangan } \\
\text { dan Jasa, Permukiman }\end{array}$ & 6,675 & 0,0119 & $-4,4335$ & $-0,0526$ \\
\hline & $\mathrm{i} 2$ & 1 & Fasilitas Pelayanan Umum & 8,504 & 0,0151 & $-4,1912$ & $-0,0634$ \\
\hline & i3 & 1 & Industri dan Pergudangan & 181,873 & 0,3235 & $-1,1285$ & $-0,3651$ \\
\hline & i4 & 1 & Perdagangan dan Jasa & 16,312 & 0,0290 & $-3,5399$ & $-0,1027$ \\
\hline & i5 & 1 & Perkantoran & 1,754 & 0,0031 & $-5,7700$ & $-0,0180$ \\
\hline & $\mathrm{i} 6$ & 1 & Permukiman & 288,696 & 0,5135 & $-0,6664$ & $-0,3422$ \\
\hline & i7 & 1 & Pertanian & 4,523 & 0,0080 & $-4,8227$ & $-0,0388$ \\
\hline & i8 & 1 & Peruntukan Khusus & 0,258 & 0,0005 & $-7,6874$ & $-0,0035$ \\
\hline & i9 & 1 & Ruang Terbuka & 52,245 & 0,0929 & $-2,3758$ & $-0,2208$ \\
\hline & $\mathrm{i} 10$ & 1 & Zona Lindung & 1,324 & 0,0024 & $-6,0513$ & $-0,0142$ \\
\hline \multicolumn{2}{|c|}{ Total } & 10 & $a=$ & 562,1635 & & & $-1,2215$ \\
\hline \multicolumn{7}{|c|}{$\operatorname{Ln}(10)$} & 2,30 \\
\hline
\end{tabular}

Sumber: Hasil Analisis, 2021. 
$E I=(-1) \times \frac{\lfloor-1,2215\rfloor}{2,30}$

$E I=0,53$

Dari contoh hasil perhitungan di atas, dapat dilihat bahwa Kelurahan Jatimulya medapatkan nilai sebesar 0,53 dengan kategorinya yaitu sedang. Agar lebih jelas mengenai hasil perhitungan analisis keragaman dilingkup desa-desa pada Kecamatan Tambun dapat melihat pada tabel berikut.

Tabel 2. Indeks Entropi Pada Keragaman Penggunaan Lahan di Kecamatan Tambun Selatan

\begin{tabular}{|l|c|c|}
\hline \multicolumn{1}{|c|}{ Desa } & Entropi Indeks & Keterangan \\
\hline Jatimulya & 0,53 & Sedang \\
\hline Lambangjaya & 0,57 & Sedang \\
\hline Lambangsari & 0,61 & Tinggi \\
\hline Mangunjaya & 0,36 & Rendah \\
\hline Mekarsari & 0,53 & Sedang \\
\hline Setiadarma & 0,64 & Sedang \\
\hline Setiamekar & 0,53 & Sedang \\
\hline Sumberjaya & 0,47 & Sedang \\
\hline Tambun & 0,67 & Tinggi \\
\hline Tridayasakti & 0,37 & Rendah \\
\hline
\end{tabular}

Sumber: Hasil Analisis, 2021

\section{Analisis Keragaman Penggunaan Lahan}

Penentuan dari kenyamanan dan layak huni di suatu wilayah dapat dilihat pada kualitas permukimannya, dengan menggunakan data yang ada dari olahan citra satelit (Google Earth dan Esri Digital Globe) yang selanjutnya dilakukan proses interpretasi objek penelitian. Interpretasi objek penelitian tersebut berdasarkan unsur-unsur kualitas permukiman untuk mengetahui kondisi yang ada pada Kecamatan Tambun Selatan, dapat dilihat sebagai berikut

1. Parameter Kepadatan Permukiman

Klasifikasi penentuan kepadatan permukiman pada penelitian ini terdiri dari tiga katergori yaitu kepadatan rendah, kepadatan sedang, dan kepadatan tinggi. Penilaian kepadatan permukiman dengan menggunakan citra diperoleh dengan menghitung luasan tutupan rumah permukiman dibagi luas blok permukiman. Permukiman yang ada di Kecamatan Tambun Selatan sangat jarang yang masuk kedalam kepadatan rendah dengan rata-rata $1,23 \%$. 
Tabel 3. Kepadatan Permukiman di Kec. Tambun Selatan

\begin{tabular}{|l|r|r|r|r|r|r|}
\hline \multirow{2}{*}{ Desa } & \multicolumn{5}{c|}{ Klasifikasi } \\
\cline { 2 - 8 } & \multicolumn{2}{|c|}{ Kepadatan Tinggi } & \multicolumn{2}{c|}{ Kepadatan Sedang } & \multicolumn{2}{c|}{ Kepadatan Rendah } \\
\cline { 2 - 8 } & Lua (Ha) & Presentase & Luas (Ha) & Presentase & Luas (Ha) & Presentase \\
\hline Jatimulya & 6.886 & $2,46 \%$ & 70.954 & $25,33 \%$ & 202.256 & $72,21 \%$ \\
\hline Lambangjaya & & & & & 136.913 & $100,00 \%$ \\
\hline Lambangsari & & & & & & \\
\hline Mangunjaya & 3.607 & $1,85 \%$ & 23.757 & $12,21 \%$ & 167.127 & $85,93 \%$ \\
\hline Mekarsari & 384 & $0,15 \%$ & 90.716 & $35,77 \%$ & 162.529 & $64,08 \%$ \\
\hline Setiadarma & & & 2.344 & $3,59 \%$ & 62.967 & $96,41 \%$ \\
\hline Setiamekar & 4.623 & $1,48 \%$ & 123.622 & $39,51 \%$ & 184.642 & $59,01 \%$ \\
\hline Sumberjaya & 7.684 & $1,34 \%$ & 121.301 & $21,10 \%$ & 445.772 & $77,56 \%$ \\
\hline Tambun & & & 1.937 & $1,36 \%$ & 140.079 & $98,64 \%$ \\
\hline Tridayasakti & 152 & $0,10 \%$ & 45.412 & $31,38 \%$ & 99.139 & $68,51 \%$ \\
\hline Rata-Rata Persentase & & $1,23 \%$ & & $19,31 \%$ & & $81,88 \%$ \\
\hline
\end{tabular}

Sumber: Hasil Analisis, 2021

Berdasarkan tabel tersebut, dapat diketahui rata-rata kepadatan di Kecamatan Tambun Selatan mendominasi pada daerah kepadatan rendah, yang artinya ruang gerak penduduk pada permukiman tersebut tergolong luas untuk melakukan berbagai aktivitas tanpa perlu takut untuk berdesak-desakan antar penduduknya, sehingga dapat menaati prokes dengan baik.

2. Parameter Tata Letak Bangunan

Parameter ini merupakan salah satu penentu atau unsur dari kualitas permukiman agar dapat melihat kondisi kenyamanan dan layak huni suatu permukiman. Jika semakin baik letak bangunan di permukimannya, maka akan memberikan dampak pada visual (keindahan dan kenyamanan), kemudian akan mempermudah pada jalur sirkulasi keluar-masuk nya kendaraan ke permukiman tersebut. Penentuan parameter ini, dengan melihat pada citra satelit pada bagian karakteristik susunan objek permukiman. Permukiman yang memiliki kondisi atau pola teratur ditinjau dari karaternya yaitu arahnya menghadap ke jalan dan juga luas tiap bangunannya relatif sama. Pada pola semi teratur dapat melihat dari kondisi bangunan dan juga luas tiap bangunannya relatif tidak seragam, namun masih ada kemiripan antar bangunannya. Dan berbanding terbalik dengan pola permukiman yang tidak teratur atau buruk, yang kondisinya dapat dilihat pada ukuran bentuk atap beragam atau tidak beraturan. Setelah dilakukan identifikasi pada permukiman di Kecamatan Tambun Selatan, maka dirata-rata didominasi oleh pola tidak teratur dengan nilai $42,36 \%$. Hasil perhitungan dari luas daerah pada tata letak bangunan tersaji pada tabel berikut.

Tabel 4. Tata Letak Bangunan di Kec. Tambun Selatan

\begin{tabular}{|l|r|r|r|r|r|r|}
\hline \multirow{2}{*}{ Desa } & \multicolumn{6}{|c|}{ Klasifikasi } \\
\cline { 2 - 7 } & \multicolumn{2}{|c|}{ Pola Tidak Teratur } & \multicolumn{2}{c|}{ Pola Semi Teratur } & \multicolumn{2}{c|}{ Pola Teratur } \\
\cline { 2 - 7 } & Luas (Ha) & Presentase & \multicolumn{1}{c|}{ Luas (Ha) } & \multicolumn{1}{c|}{ Presentase } & \multicolumn{1}{c|}{ Luas (Ha) } & Presentase \\
\hline Jatimulya & 162.100 & $56,04 \%$ & 64.824 & $22,41 \%$ & 62.310 & $21,54 \%$ \\
\hline \multirow{2}{*}{ Lambangjaya } & & & & & & \\
& 65.951 & $48,17 \%$ & 8.752 & $6,39 \%$ & 62.210 & $45,44 \%$ \\
\hline
\end{tabular}




\begin{tabular}{|c|c|c|c|c|c|c|}
\hline \multirow{3}{*}{ Desa } & \multicolumn{6}{|c|}{ Klasifikasi } \\
\hline & \multicolumn{2}{|c|}{ Pola Tidak Teratur } & \multicolumn{2}{|c|}{ Pola Semi Teratur } & \multicolumn{2}{|c|}{ Pola Teratur } \\
\hline & Luas (Ha) & Presentase & Luas $(\mathrm{Ha})$ & Presentase & Luas $(\mathrm{Ha})$ & Presentase \\
\hline Lambangsari & 44.524 & $25,41 \%$ & 105.505 & $60,21 \%$ & 25.206 & $14,38 \%$ \\
\hline Mangunjaya & 68.882 & $33,08 \%$ & 13.726 & $6,59 \%$ & 125.610 & $60,33 \%$ \\
\hline Mekarsari & 133.584 & $52,67 \%$ & 11.581 & $4,57 \%$ & 108.465 & $42,77 \%$ \\
\hline Setiadarma & 25.289 & $38,72 \%$ & 31.403 & $48,08 \%$ & 8.620 & $13,20 \%$ \\
\hline Setiamekar & 119.443 & $38,17 \%$ & 21.598 & $6,90 \%$ & 171.846 & $54,92 \%$ \\
\hline Sumberjaya & 177.011 & $30,80 \%$ & 79.005 & $13,75 \%$ & 318.740 & $55,46 \%$ \\
\hline Tambun & 90.890 & $64,00 \%$ & 25.554 & $17,99 \%$ & 25.573 & $18,01 \%$ \\
\hline Tridayasakti & 52.849 & $36,52 \%$ & 18.466 & $12,76 \%$ & 73.389 & $50,72 \%$ \\
\hline $\begin{array}{l}\text { Rata-Rata } \\
\text { Persentase }\end{array}$ & & $42,36 \%$ & & $19,97 \%$ & & $37,68 \%$ \\
\hline
\end{tabular}

Sumber: Hasil Analisis, 2021

3. Parameter Lebar Jalan Masuk

Parameter ini melihat pada lebar jalan masuk suatu permukiman karena berkaitan dengan kenyamanan mobilisasi terkhusus yang membutuhkan pertolongan salah satunya pasien terkonfirmasi Positif Covid-19 dengan komorbid, yang membutuhkan akses yang mudah untuk menjangkau lokasi pasiennya. Pemberian bobot nilai sesuai dengan kriteria yang ada maka disandingkan dengan identifikasi pada citra satelit (Esri Digital Globe) dan juga street view (Google Earth) kemudian dibagi kedalam tiga kategori yaitu kelas jalan lebar dengan asumsi dapat dilewat oleh dua hingga tiga mobil berpapasan atau $>6$ meter. Dengan lebar jalan 4 hingga 6 meter di kategorikan dengan nilai harkat dua atau kriteria sedang. Sedangkan jalan dengan lebar < 4 meter dikategorikan kedalam harkat satu atau masuk ke kriteria buruk. Dari hasil yang dilakukan melalui identifikasi pada area-area permukiman, dapat diketahui lebar jalan masuknya ke permukiman.
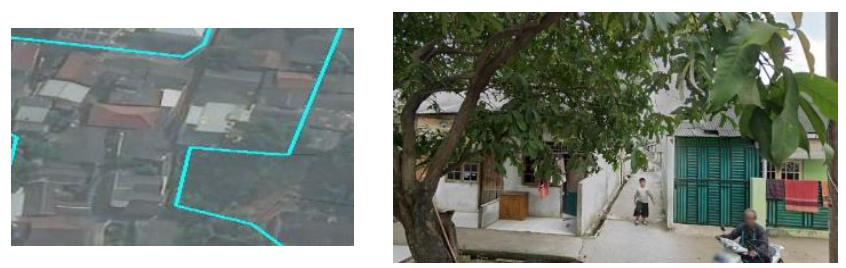

Gambar 3. Lebar Jalan Kriteria Buruk Tampak Citra dan Landscape

Sumber: Google Earth, 2021
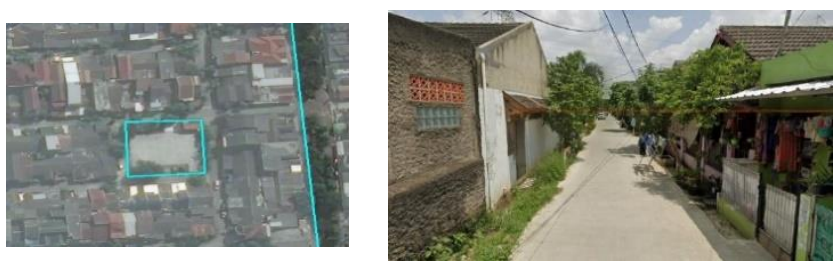

Gambar 4. Lebar Jalan Kriteria Sedang Tampak Citra dan Landscape

Sumber: Google Earth, 2021 

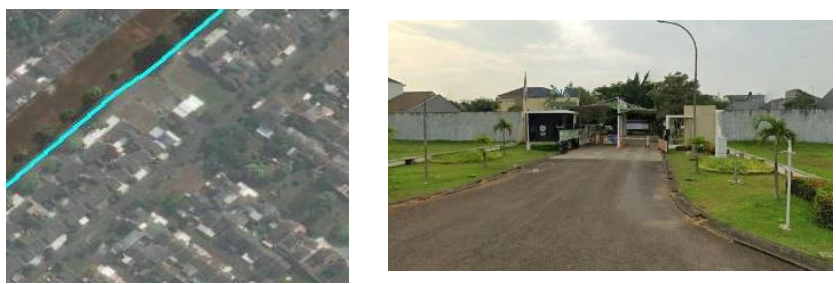

Gambar 5. Lebar Jalan Kriteria Baik Tampak Citra dan Landscape

Sumber: Google Earth, 2021

4. Parameter Kondisi Jalan Masuk

Pada parameter ini, dapat melihat pada keadaan jalan masuk ke area permukiman. Dasar penilaian yang dibagi ke dalam tiga kategori (baik, sedang, buruk) adalah dengan melohat perkerasan jalannya tersebut sudah di aspal dan/ semen atau belum. Pada kondisi penelitian, seluruhnya mempunyai kondisi yang baik dengan perkerasan (aspal, beton, ataupun coneblock), hanya beberapa bagian permukiman yang belum dilakukan perkerasan.

5. Parameter Lokasi Permukiman

Lokasi di suatu permukiman dibagi kedalam tiga kategori yaitu baik, sedang dan buruk. Parameter ini didasarkan kepada posisi atau letak suatu permukiman terhadap sumber-sumber polusi baik dikarnakan aktivitas pengolahan pabrik maupun kendaraan yang keluar-masuk ke lokasi tersebut. Kondisi kelas yang baik itu lokasi permukimannya jauh dari sumber-sumber polusi (pabrik, jalan ateri, dan sebagainya), sedangkan dengan kondisi kelas sedang adalah lokasi permukiman yang berdekatan dengan lokasi sumber-sumber polusi namun tidak terpengaruh secara langsung dampaknya pada kenyamanan bermukim. Sedangkan yang masuk ke dalam kategori buruk adalah lokasi permukiman yang berada di daerah sumber polusi (kebisingan, udara, dan sebagainya). Asumsi yang digunakan pada parameter ini yaitu jika suatu permukiman yang berdekatan dengan sumber polusi (kebisingan, udara, dan sebagainya), maka kenyamanan dan layak huni di permukiman tersebut masuk ke dalam kualitas buruk dan sebaliknya. Sumber polusi yang ada pada daerah penelitian ini berupa polusi udara dari pabrikpabrik, dan kebisingan baik dari kereta api atau pun kendaraan yang bermobilitas tinggi di suatu jalan arteri dan/ jalan raya.

6. Parameter Pohon Pelindung

Pada parameter pohon pelindung mempunyai pengaruh pada kenyamanan disekitar lingkungan permukiman salah satunya pada aspek mendapatkan sirkulasi udara yang segar. Dalam penelitian ini mengasumsikan dengan adanya pohon pelindung pada permukiman maka permukiman tersebut mendapat nilai kenyamanan dan layak huni yang baik, salah satunya pada keteduhan di sepanjang jalan maupun visual yang indah. Untuk penilaian parameter ini terbagi menjadi dua kategori yaitu baik (terdapat pohon pelindung) dan buruk (tidak terdapat pohon pelindung sama sekali).

Dengan unsur-unsur parameter di atas, maka didapatkan kondisi secara umum di desadesa pada Kecamatan Tambun Selatan dengan klasifikasi total harkat pada gambar 5 berikut. 


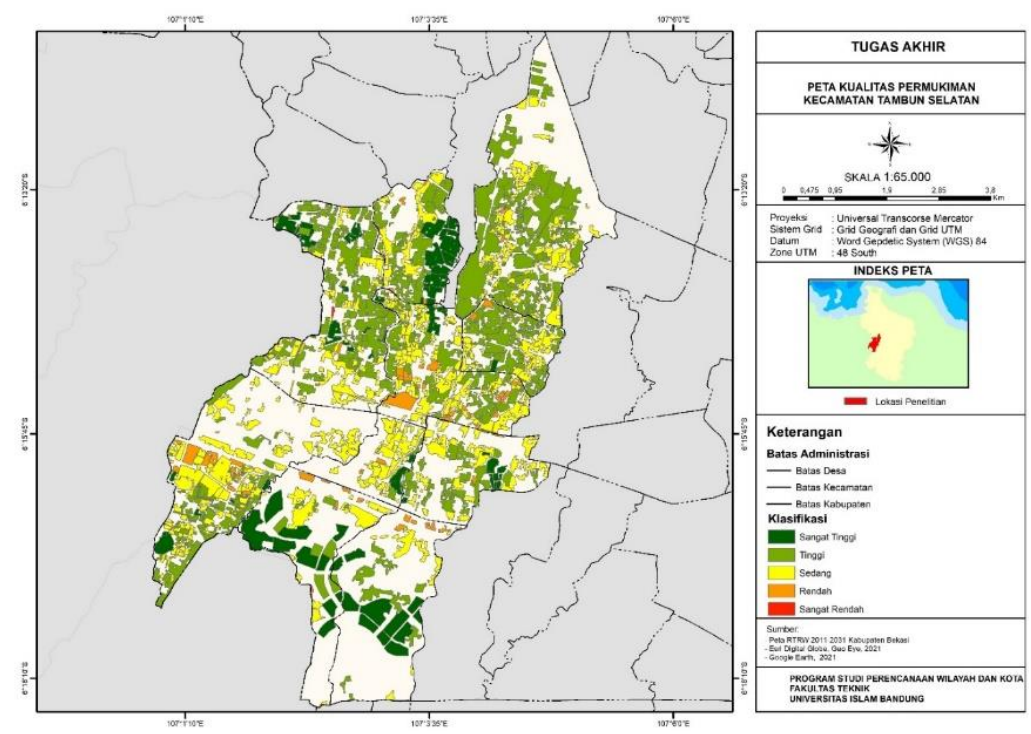

Gambar 6. Peta Kualitas Permukiman di Kecamatan Tambun Selatan

Sumber: Diolah oleh Peneliti, 2021

Analisis Pengaruh Keruangan Terhadap Proprosi angka kesembuhan Covid-19 di Kecamatan Tambun Selatan

Setelah dilakukan proses analisis diatas, maka penelitian ini melakukan pemodelan statistik yaitu regresi linier berganda atau regresi majemuk dengan penggunaan datanya yang terangkum pada tabel 5 berasal dari data sekunder sehingga didapatkan beberapa hasil yang dilakukan penjabaran serta pengujiannya pada tabel dibawah ini.

Tabel 5. Tabulasi Data Variabel Penelitian

\begin{tabular}{|c|c|c|c|c|c|}
\hline \multirow{2}{*}{$\begin{array}{c}\text { Desa/ } \\
\text { Kelurahan }\end{array}$} & \multicolumn{4}{|c|}{ Variabel Bebas } & Variabel Terikat \\
\hline & RTH (Ha) & $\mathrm{PL}$ & $\mathrm{KLH}(\%)$ & FP (Unit) & $\mathrm{AKC}(\%)$ \\
\hline Jatimulya & 53,48 & 0,53 & 1,71 & 3 & 99,47 \\
\hline Lambangjaya & 89,17 & 0,57 & 1,35 & 0 & 99,44 \\
\hline Lambangsari & 46,25 & 0,61 & 0,91 & 2 & 97,53 \\
\hline Mangunjaya & 28,92 & 0,36 & 1,98 & 1 & 98,71 \\
\hline Mekarsari & 42,62 & 0,53 & 1,85 & 2 & 98,30 \\
\hline Setiadarma & 21,26 & 0,64 & 0,34 & 1 & 99,62 \\
\hline Setiamekar & 78,64 & 0,53 & 3,12 & 2 & 98,71 \\
\hline Sumberjaya & 109,44 & 0,47 & 3,06 & 1 & 98,38 \\
\hline Tambun & 36,69 & 0,67 & 2,12 & 1 & 98,31 \\
\hline Tridayasakti & 24,79 & 0,37 & 3,46 & 1 & 100,00 \\
\hline
\end{tabular}

Sumber: Hasil Analisis, 2021 
Tabel 6. Hubungan dan Pengaruh Antara Variabel Bebas dengan Variabel Terikat

\begin{tabular}{|l|c|c|c|c|}
\hline Variabel & $\mathbf{r}_{\mathbf{s}}$ & $\mathbf{F}_{\text {hitung }}$ & $\mathbf{F}_{\text {tabel }}$ & Hubungan/ Pengaruh \\
\hline $\mathrm{X}$ dan Y & 0,174 & 0,263 & 0.112 & H1 Diterima (Ada Hubungan) \\
\hline
\end{tabular}

Sumber: Hasil Analisis, 2021

Berdasarkan tabel di atas, dapat diketahui besaran hubungan antara variabel-variabel bebas (Luas RTH, Keragaman Penggunaan Lahan, Kenyamanan dan Layak Huni, dan Fasyankes Penanganan Covid-19) dengan variabel Angka Kesembuhan Covid-19 sebesar 0,174 atau $17,4 \%$, sedangkan sisanya dengan nilai $83,6 \%$ dipengaruhi oleh berbagai hal salah satunya faktor kesehatan (imun tubuh) yang posisinya diluar dari variabel dalam penelitian ini. Pengaruh yang didapatkan berdasarkan hasil pengujian regresi majemuk didapatkan nilai sebesar Fhitung 0,263 > Ftabel 0,112 dengan arti hipotesis ada pengaruh antara variabel independen (luas rth, kenyamanan/ kualitas permukiman, keragaman penggunaan lahan, dan fasyankes penanganan Covid-19) dengan variabel proprosi angka kesembuhan Covid-19 di Kecamatan Tambun Selatan.

Hasil dari penelitian ini, dapat terlihat bahwa kondisi keruangan pada desa/kelurahan yang berada di Kecamatan Tambun Selatan, baik kondisi permukiman yang tertata atau sebaliknya, jumlah ruang terbuka dan/hijau, hingga jumlah ketersediaan Fasilitas Layanan Kesehatan (Fasyankes) penanganan Covid-19 di wilayahnya, hanya berpengaruh sedikit terhadap kesembuhan pada wabah penyakit Covid-19. Akan tetapi, karena salah satu faktor penggunaan lahan yang ada pada desa/kelurahan Kecamatan Tambun Selatan masuk ke dalam kategori rata-rata sedang, maka dapat mengurangi berbagai aktivitas masyarakat yang membutuhkan mobilisasi, cukup dengan melakukan pergerakan di wilayah tempat tinggalnya dalam memenuhi kebutuhan bahan pokok yang sejalan dengan upaya penanganan Covid-19 dari Pemerintah yaitu membatasi perjalan, agar meminimalisir penyebaran Covid-19 yang akan terjadi di wilayah desa/ kelurahan di Kecamatan Tambun Selatan.

\section{Kesimpulan}

Dalam penelitian ini, melalui serangkaian analisis untuk melihat keterpengaruhan keruangan terhadap kesembuhan Covid-19 di Kecamatan Tambun Selatan, Terdapat hubungan antara variabel kerungan pada aspek lingkungan dan fisik dengan angka kesembuhan Covid-19 sebagai variabel terikatnya. Dengan berbagai kondisi ruang di Tambun Selatan pada penelitian ini seperti 1) jumlah RTH yang pada umumnya dapat menurukan kadar dari polutan pada wilayah tersebut, namun pada kondisi untuk kesembuhan Covid-19 tidak dipengaruhi, namun tetap dapat memberikan udara segar maupun aktivitas fisik yang dapat dilakukan oleh penduduk lingkungan sekitarnya, 2) keragaman dari penggunaan lahan di berbagai desa/kelurahan yang ada, dapat meminimalisir pergerakan individu untuk memenuhi berbagai kebutuhan khususnya bahan pokok, 3) kenyaman dan layak huni dari berbagai kondisi permukiman (tertata dan teratur ataupun sebaliknya) pada umumnya mempunyai keselarasan dengan kualitas hidup masingmasing individunya, namun jika terkait imun atau daya tahan tubuh untuk pemulihan pada Covid-19 kondisi tersebut tidak mempengaruhinya, dan 4) jumlah fasilitas layanan Kesehatan untuk penanganan Covid-19 seperti Rumah Sakit maupun Puskesmas tidak mempunyai dampak secara signifikan pada kesembuhan Covid-19 dikarenakan secara alamiah orang yang suspek Covid-19 dapat sembuh, namun Fasyankes tersebut dengan tenaga Kesehatan yang ada dapat membantu dalam memantau kondisi kesehatan masyarakat pada wilayahnya. Oleh karenanya dapat diartikan bahwa keruangan tidak dapat dipisahkan dengan suatu kondisi permasalahan kesehatan masyarakat di Kecamatan Tambun Selatan, walaupun secara tidak langsung hubungannya, namun dapat mempengaruhi akan kesembuhan pada penyakit Covid-19 di masyarakat. 


\section{Acknowledge}

Penulis mengucapkan terima kasih banyak kepada kedua orang tua penulis, Ibu Chusharini Chamid, IR., M.ENV. selaku dosen pembimbing yang selalu memberikan arahan, masukan, serta motivasi selama proses menyelesaikan karya tulis ini, dan pihak-pihak yang belum bisa penulis cantumkan secara keseluruhan dalam membantu penelitian ini.

\section{Daftar Pustaka}

[1] Pangarso FB, Anindyasarathi A. Desain Lingkungan-binaan di Indonesia dalam menghadapi fenomena perkembangan teknologi di awal abad XXI [Internet]. Bandung; 2017 Nov. Available from: http://www.oxforddictionaries.com/definition/english/designative.

[2] Husain MN, Giyarsih SR. Kajian Kualitas Permukiman Mikro Di Kota Temanggung. J Bumi Indones [Internet]. 2016;5. Available from: http://lib.geo.ugm.ac.id/ojs/index.php/jbi/article/view/427

[3] Li X, Wang C, Zhang G, Xiao L, Dixon J. Urbanisation and human health in China: Spatial features and a systemic perspective. Environ Sci Pollut Res [Internet]. 2012;19(5):137584. Available from: https://link.springer.com/article/10.1007/s11356-011-07187?error=cookies_not_supported\&code=57235923-6921-4be5-9a4e-1341169be230

[4] Priyono, Jumadi, Kurniasari MI. Pengukuran Kualitas Permukiman Hubungannya Dengan Tingkat Kesehatan Masyarakat Di Kecamatan Sragen: Upaya Awal Untuk Peningkatan Kapasitas Masyarakat Dalam Strategi Pengurangan Resiko Penyakit. Geo Edukasi. 2013;2:52-9.

[5] Keil R, Connolly C, Ali SH. Outbreaks like coronavirus start in and spread from the edges of cities. The Conversation. 2020. p. 1-6.

[6] Segnita A, Handayani W. Pengukuran Penggunaan Lahan Campuran (Mixed Used) dengan Indeks Entropy di Kota Semarang. Riptek. 2017;II(2):135-50.

[7] 7. Farizki M, Anurogo W. Pemetaan kualitas permukiman dengan menggunakan penginderaan jauh dan SIG di kecamatan Batam kota, Batam. Maj Geogr Indones. 2017;31(1):39. 